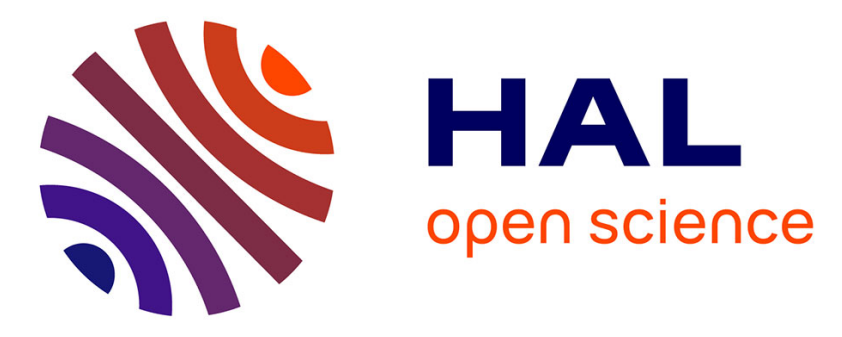

\title{
Bioinspired symmetrical and unsymmetrical diiron complexes for selective oxidation catalysis with hydrogen peroxide
}

Alexandre Trehoux, Régis Guillot, Martin Clemancey, Geneviève Blondin, Jean-Marc Latour, Jean-Pierre Mahy, Frédéric Avenier

\section{To cite this version:}

Alexandre Trehoux, Régis Guillot, Martin Clemancey, Geneviève Blondin, Jean-Marc Latour, et al.. Bioinspired symmetrical and unsymmetrical diiron complexes for selective oxidation catalysis with hydrogen peroxide. Dalton Transactions, 2020, 49 (46), pp.16657-16661. 10.1039/d0dt03308a . hal03087311

\section{HAL Id: hal-03087311 https://hal.science/hal-03087311}

Submitted on 25 Nov 2021

HAL is a multi-disciplinary open access archive for the deposit and dissemination of scientific research documents, whether they are published or not. The documents may come from teaching and research institutions in France or abroad, or from public or private research centers.
L'archive ouverte pluridisciplinaire HAL, est destinée au dépôt et à la diffusion de documents scientifiques de niveau recherche, publiés ou non, émanant des établissements d'enseignement et de recherche français ou étrangers, des laboratoires publics ou privés. 


\title{
Bioinspired Symmetrical and Unsymmetrical Diiron
}

\section{Complexes for Selective Oxidation Catalysis with}

\section{Hydrogen Peroxide}

Alexandre Tréhoux, ${ }^{a}$ Régis Guillot, ${ }^{a}$ Martin Clemancey, ${ }^{b}$ Geneviève Blondin, ${ }^{b}$ JeanMarc Latour, ${ }^{\mathrm{b}}$ Jean-Pierre Mahy ${ }^{\mathrm{a} *}$ and Frédéric Avenier ${ }^{\mathrm{a} *}$

a Université Paris-Saclay, CNRS, Institut de Chimie Moléculaire et des Matériaux d'Orsay, Equipe de Chimie Bioorganique et Bioinorganique, 91405 Orsay, France.

b Université Grenoble Alpes, CEA, CNRS, IRIG, DIESE, LCBM, pmb, F-38000 Grenoble, France.

\begin{abstract}
Two new symmetrical and unsymmetrical diiron(III) complexes were synthesized and characterized by X-ray diffraction analysis, mass spectrometry, UV-Visible and Mössbauer spectroscopies. They proved to be good catalysts for alkene and alkane oxidation reactions by $\mathrm{H}_{2} \mathrm{O}_{2}$ in acetonitrile solution, and interesting effects of both the nature and the symmetry of the complexes were observed on catalysis in the presence of water.
\end{abstract}

Soluble methane monooxygenase (MMOs), present in methanotrophic bacteria, converts methane to methanol thanks to the reductive activation of dioxygen at its dinuclear iron center. ${ }^{1}$ Upon interaction with dioxygen, this enzyme forms an unstable bridging diiron(III)-peroxo intermediate $(\mathrm{P})^{2}$ which evolves into a catalytically active diiron(IV) di-oxo intermediate (Q). ${ }^{3}$ This enzyme belongs to a large family of dinuclear iron proteins which bind dioxygen rather similarly but activate it for different catalytic purposes. ${ }^{2,4}$ Overall, the stability and reactivity of these intermediates seem 
to be finely tuned by subtle differences in the first and second coordination spheres of the $\mathrm{Fe}$ ions present in the active sites. Enhancing the knowledge about the influence of the coordination sphere, and more generally about the microenvironment surrounding metal ions, is therefore of great interest, not only to better understand enzyme mechanisms, but also to improve the efficiency and selectivity of bioinspired catalysts.

Numerous di-nuclear iron complexes can generate $\mu$-peroxo diiron(III) intermediates upon addition of dioxygen or hydrogen peroxide,${ }^{5}$ and their spectroscopic parameters are now well established. ${ }^{6-17}$ Some attempts have been made to study the influence of structural and environmental changes on the activity of these diiron complexes. For example, the stability of diron(III) peroxo species have been evaluated in different solvents, and it was shown that strongly coordinating ligands such as DMSO helped stabilizing the peroxo intermediate. ${ }^{10}$ Introducing bulkiness around the metals in symmetrical ${ }^{9}$ and unsymmetrical alkoxide bridging ligands in diiron complexes, ${ }^{12}$ was shown to slow down the formation of the peroxo intermediate. Finally, diron complexes of bulky carboxylate-rich ligands were also studied ${ }^{18}$ and led to the observation of a superoxo species upon interaction of the diiron(II) center with dioxygen. ${ }^{19}$ The effect of pyridyl ligands bearing electron-donating or electronwithdrawing pyridyl ligands have also been studied with mononuclear iron complexes, ${ }^{20-23}$ but very few examples of diron complexes are known to date. Que and co-workers have developed di-nuclear iron complexes based on $\mu$-oxo-bridged mono-nucleating units bearing electron donating groups, which allowed the characterization of the first diiron(IV) di-oxo synthetic intermediate. ${ }^{24}$ The same complex also led to the formation of a dinuclear high spin iron(IV)-oxo intermediate with a good specificity for hydrogen abstraction catalysis. ${ }^{25}$ Finally, another diiron(IV) 
complex bearing electron donating pyridyl ligands was also demonstrated to cleave strong $\mathrm{C}-\mathrm{H}$ and $\mathrm{O}-\mathrm{H}$ bonds. ${ }^{26}$ Overall, very few studies focus on non-symmetrical diiron complexes with the aim to address the influence of symmetry on dioxygen or hydrogen peroxide activation at diiron centers. In terms of catalysis, examples of the use of diron complexes for oxidation reactions are very scarce and most of the reported examples lead to intra-molecular oxidation of the ligands using dioxygen or hydrogen peroxide. ${ }^{27-29}$ The best non-heme diron catalyst known to date for olefin epoxidation is a complex based on a TPA like di-nucleating ligand which catalyzes the epoxidation of cyclooctene with a good selectivity and high turnover numbers. ${ }^{30}$ This catalyst is also an excellent functional model of MMOs since both the diiron(III) peroxo and the diiron(IV) di-oxo intermediates have been characterized prior to olefin epoxidation. ${ }^{31}$ Furthermore, this complex was also demonstrated to be capable of cleaving strong $\mathrm{C}-\mathrm{H}$ bonds in good yields. ${ }^{32}$

Here, we report the synthesis, characterization, and catalytic activity for selective oxidation, of two new diiron complexes bearing electron-donating pyridyl groups in a symmetrical (complex [3]) and unsymmetrical way (complex [2]) (Fig. 1). The effects of the nature and the symmetry of the ligand in these complexes, on the catalytic oxidation of different substrates by $\mathrm{H}_{2} \mathrm{O}_{2}$, were evaluated and compared to those previously described with complex [1]. ${ }^{33}$ 
a

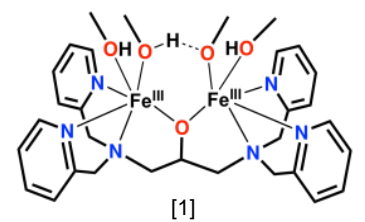

[1]

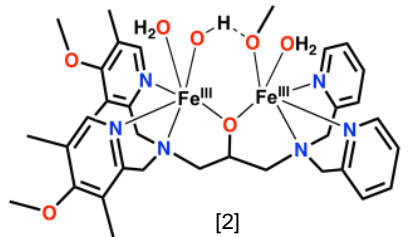

[2]

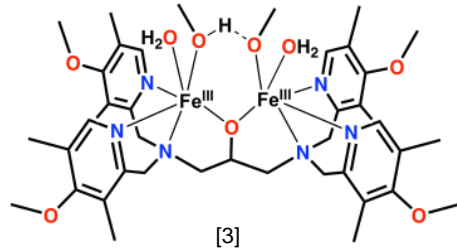

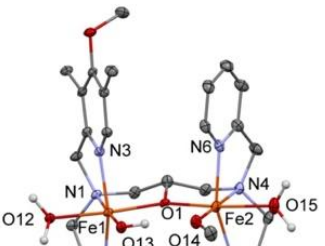
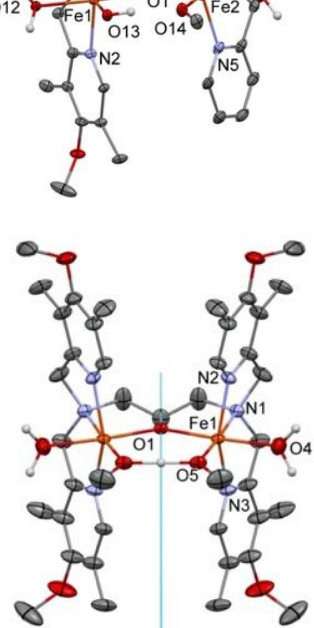

Figure 1. a) Symmetrical [1], [3] and unsymmetrical [2] diiron complexes used in this study. b) X-ray crystal structures of complexes [2] (top) and [3] (bottom). (See S.I., tables S1 and S2)

The three ligands used in this study have all been synthesized via synthetic methods adapted from Suzuki and coll. ${ }^{12}$ and the three corresponding diiron complexes were obtained by addition of two equivalents of $\mathrm{Fe}(\mathrm{III})\left(\mathrm{ClO}_{4}\right)_{3}$ as described in supporting information. Slow diffusion of diethyl ether into these solutions yielded crystals suitable for X-ray diffraction analysis, and the structures of [2] and [3] are presented in Fig.1b. As previously described for [1], ${ }^{33}$ in both complexes [2] and [3], the two metal ions are hexacoordinated with a distorted octahedral geometry and each bear two exogenous ligands. In all cases, the two iron ions are bridged by the alkoxy group of the ligand and each iron binds two pyridyl groups in a trans geometry. Interestingly, both [1] and [3] are perfectly symmetrical, including the exogenous ligands, while [2] presents both an unsymmetrical bi-nucleating ligand and different exogenous ligands coordinated to iron(1) and iron(2). 
The Mössbauer spectra of [1], [2], and [3] were recorded in the solid state at $5 \mathrm{~K}$ (Fig. S1). All appear as a single quadrupole doublet accounting for $100 \%$ of the signal. The spectrum of [1] is a relatively narrow quadrupole doublet $(\Gamma$ ca $0.33 \mathrm{~mm}$ $\mathrm{s}^{-1}$ ) which can be simulated by a single Fe site with an isomer shift $\delta=0.46(2) \mathrm{mm} \mathrm{s}^{-1}$ and a quadrupole splitting $\Delta \mathrm{E}_{\mathrm{Q}}=1.02(4) \mathrm{mm} \mathrm{s}^{-1}$ showing that the two $\mathrm{Fe}$ ions are too similar to be distinguished. These parameters are consistent with high-spin Fe(III) ions with a tetragonal $\mathrm{O} / \mathrm{N}$ environment. The spectrum of [3] can be simulated similarly by considering two identical high-spin iron(III) sites with the following parameters $\delta=0.42(2) \mathrm{mm} \mathrm{s}^{-1}, \Delta \mathrm{E}_{\mathrm{Q}}=0.84(4) \mathrm{mm} \mathrm{s}^{-1}$ and $\Gamma$ ca $0.33 \mathrm{~mm} \mathrm{~s}^{-1}$. Finally, the Mössbauer spectrum of [2] is constituted by a quadrupole doublet with similar isomer shift and quadrupole splitting, but much larger linewidth than that of [1] and [3] $\left(\delta=0.42(2) \mathrm{mm} \mathrm{s}^{-1}, \Delta \mathrm{E}_{\mathrm{Q}}=0.99(4) \mathrm{mm} \mathrm{s}^{-1}, \Gamma\right.$ ca $\left.0.41 \mathrm{~mm} \mathrm{~s}^{-1}\right)$ (Fig. 2a and Fig. S1). This increased linewidth undoubtedly reflects the difference of the two Fe sites. To investigate more in depth the effect of this difference on the Mössbauer parameters of the two iron ions, we performed simulations of the spectrum of [2] taking into account different individual sites. As shown in Fig. 2b, the experimental spectrum can be reproduced quite satisfactorily based on equal contributions of two sites with parameters and linewidths close to those of [1] and [3] $\left(\delta=0.42(2) \mathrm{mm} \mathrm{s}^{-1}\right.$, $\Delta \mathrm{E}_{\mathrm{Q}}=1.18(4) \mathrm{mm} \mathrm{s}^{-1}$ and $\delta=0.42(2) \mathrm{mm} \mathrm{s}^{-1}, \Delta \mathrm{E}_{\mathrm{Q}}=0.79(4) \mathrm{mm} \mathrm{s}^{-1}$, common linewidth $\Gamma=0.32 \mathrm{~mm} \mathrm{~s}^{-1}$ ). Accordingly, Mössbauer spectroscopy allowed to evidence the differences between the two iron sites in the unsymmetrical complex [2].

UV-visible spectra of [1], [2], and [3] were recorded in acetonitrile (Fig. 3), and each complex showed similar spectra with two $\pi-\pi^{*}$ transition bands in the regions between 200 and $220 \mathrm{~nm}$ and between 260 and $270 \mathrm{~nm}$, as well as a third band 
between $350 \mathrm{~nm}$ and $370 \mathrm{~nm}\left(\varepsilon \approx 10000 \mathrm{M}^{-1} \mathrm{~cm}^{-1}\right)$. For the highest energy band, the molar extinction coefficient was proportional to the amount of donating substituents on the pyridyl ligands present in the complex, with the $\varepsilon$ values of $\varepsilon=94000 \mathrm{M}^{-1} \mathrm{~cm}^{-1}$ for complex [3], $\varepsilon=74000 \mathrm{M}^{-1} \mathrm{~cm}^{-1}$ for complex [2] and $\varepsilon=60000 \mathrm{M}^{-1} \mathrm{~cm}^{-1}$ for [1]. The characterization of the three complexes in solution was then completed by high resolution mass spectrometry analysis which are described in supporting information.

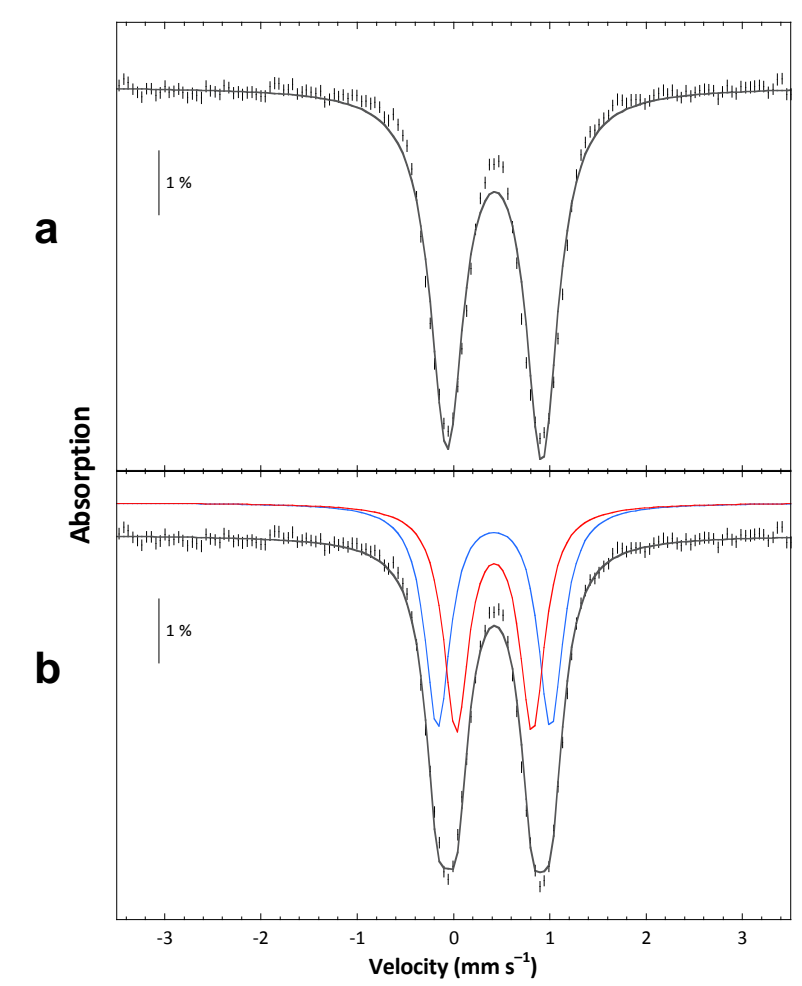

Figure 2. Simulations of the Mössbauer spectra of complex [2] in solid state (hatched bars) recorded at $5 \mathrm{~K}$ and calculated fit (black solid line) taking into account: a) a single quadrupole doublet with parameters $\delta=0.42(2) \mathrm{mm} \mathrm{s}^{-1}, \Delta \mathrm{E}_{\mathrm{Q}}=0.99(4) \mathrm{mm} \mathrm{s}^{-1}, \Gamma$ ca $0.41 \mathrm{~mm} \mathrm{~s}^{-1}$ ) and b) equal contributions of two high-spin iron(III) species with parameters $\delta=0.42(2) \mathrm{mm} \mathrm{s}^{-1}, \Delta \mathrm{E}_{\mathrm{Q}}=1.18(4) \mathrm{mm} \mathrm{s}^{-1}$ (blue line) and $\delta=0.42(2) \mathrm{mm} \mathrm{s}^{-1}, \Delta \mathrm{E}_{\mathrm{Q}}=0.79(4) \mathrm{mm} \mathrm{s}^{-1}$ (red line), common linewidth $\Gamma=0.32 \mathrm{~mm} \mathrm{~s}^{-1}$. 


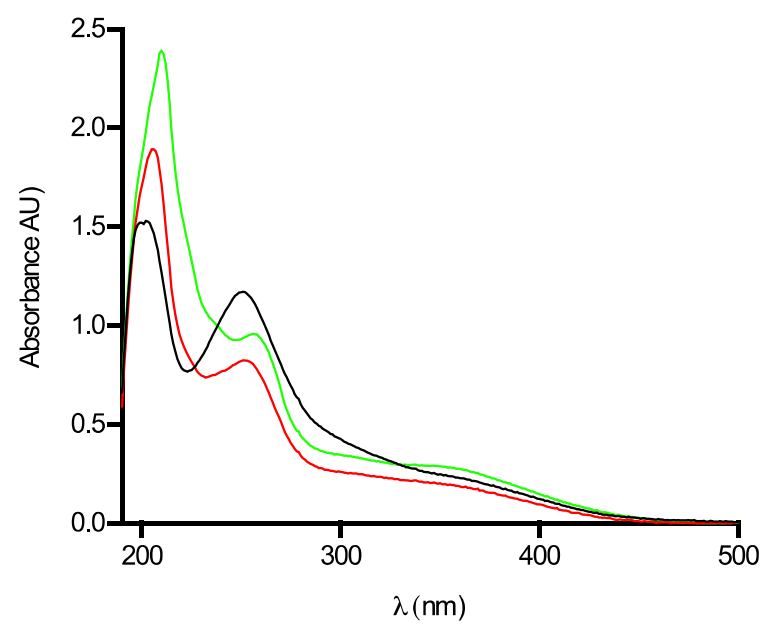

Figure 3. UV-visible spectra of complexes [1] (black line), [2] (red line) and [3] (green line) in $25 \mu \mathrm{M}$ acetonitrile solution.

The three complexes were then tested for the catalytic oxidation of sulfides, alkenes and alkanes by $\mathrm{H}_{2} \mathrm{O}_{2}$. All the experiments were performed at room temperature, in triplicate, under aerobic conditions, using a syringe pump system. The results obtained for the different substrates are summarized in Table 1. The epoxidation of cyclooctene was first investigated using 10 equivalents of $\mathrm{H}_{2} \mathrm{O}_{2}$ with respect to the catalyst, and solely epoxide was obtained as product in good yields, ranging from 73 to $79 \%$. These results are comparable to those reported for the best di-nuclear iron complex known to date for the catalytic epoxidation of cyclooctene, both in terms of selectivity and yields. ${ }^{30}$ When a larger amount of hydrogen peroxide was added (200 equiv.), the high selectivity for the epoxide was conserved, but the yields did not exceed $23 \%$, pointing out the limit of these catalysts for cyclooctene epoxidation (46 turn-overs). As one could expect, moving to oxidation of cyclohexene gave a different selectivity with rather high yields for allylic oxidation (40 to $50 \%$ ) and very low yields for epoxidation (less than 3\%). For these two alkenes, no tendency could be drawn depending on the structure of the complex. The catalytic activity was then evaluated 
for the oxidation of thioanisole that gives almost exclusively the sulfoxide product with only traces of sulfone. Complex [3] was the best catalyst for sulfoxidation leading to a $70 \%$ conversion, but the yield decreased to $48.5 \%$ and then $24.6 \%$ for [2] and [1] respectively. In this case, the more donating groups are present, the more active is the complex. However, the symmetry of the complex does not seem to have an effect. Finally, hydrogen abstraction catalysis was also explored with four substrates bearing $\mathrm{C}\left(\mathrm{sp}^{3}\right)-\mathrm{H}$ bonds with $\mathrm{BDE}$ ranging from $82 \mathrm{kcal} \mathrm{mol}^{-1}$ for diphenylmethane, to $98 \mathrm{kcal} \mathrm{mol}^{-1}$ for cyclohexane. Diphenylmethane and ethylbenzene (BDE $=87 \mathrm{kcal}$ $\mathrm{mol}^{-1}$ ) gave very similar results with about 50 to 58 turnovers for the three complexes. In the case of toluene $\left(\mathrm{BDE}=90 \mathrm{kcal} \mathrm{mol}^{-1}\right)$ the yields went down to about 8 turnovers and the oxidation of cyclohexane $\left(B D E=98 \mathrm{kcal} \mathrm{mol}^{-1}\right)$ gave rather similar results with about 10 turnovers. The drop in activity for a BDE value above $90 \mathrm{kcal}$ $\mathrm{mol}^{-1}$ indicates the limits of these complexes in terms of oxidation capacities. No clear effect of the coordination sphere or the symmetry of complex could be observed for $\mathrm{C}-\mathrm{H}$ activation, neither in terms of yield, nor in terms of selectivity. Yet, the microenvironment of enzyme's active sites is not restricted to the variety or the symmetry of the iron coordination spheres and the presence of water into their hydrophobic microenvironment may also influence catalysis. We have therefore performed catalysis with increasing amounts of water into the acetonitrile solution. No clear effect could be observed for cyclohexane, cyclohexene or thioanisole, but some interesting results were obtained for diphenylmethane and cyclooctene, as reported in Fig. 4. First of all, one can observe that the catalytic activity is almost completely lost above $20 \%$ of water added for cyclooctene and $5 \%$ for diphenylmethane. In the latter case, the activity is completely lost above $2 \%$ of water for complex [1], but the progressive introduction of electron-donating groups in [2] and [3] clearly helped to 
maintain activity with low proportion of water, with even a gain of activity of $1 / 3$ for complex [3] when $1 \%$ of water was added. Concerning the oxidation of cyclooctene, the symmetrical incorporation of electron donating groups in [3] did not change very much the catalytic behavior compared to [1]. However, the unsymmetrical character of [2] clearly influenced both the yield and the selectivity of the reaction when about $5 \%$ of water was added to the acetonitrile solution. For example, when $6 \%$ of water was added, the overall yield (epoxide + diol) obtain with [2] was 28-fold higher than with [1] and 12-fold higher than with [3]. More interestingly, the addition of water did not change the selectivity in the case of the symmetrical complexes [1] and [3], but drastically modified the one of the unsymmetrical complex [2] with a $20 \%$ yield in diol formed for $2 \%$ of water added, which is 200 -fold higher than for [1] and 10-fold higher than for [2]. Since these differences may be arising from various parameters, we are now exploring in more details this interesting behavior.

Table 1. Catalysis experiments in $\mathrm{MeCN}$, at room temperature, with a syringe pump over 30 minutes.

\begin{tabular}{|c|c|c|c|c|c|}
\hline \multirow[t]{2}{*}{ Substrate } & \multirow[t]{2}{*}{ Cata. } & \multicolumn{3}{|c|}{ Products (TON) } & \multirow[t]{2}{*}{ Yield(\%) } \\
\hline & & \multicolumn{2}{|l|}{ Epoxide } & Diol & \\
\hline & [1] & \multicolumn{2}{|l|}{$7.8( \pm 0.5)^{\mathrm{a}}$} & - & $78.0^{\mathrm{a}}$ \\
\hline & [2] & \multicolumn{2}{|l|}{$7.9( \pm 0.2)^{\mathrm{a}}$} & - & $79.0^{\mathrm{a}}$ \\
\hline & [3] & \multicolumn{2}{|l|}{$7.3( \pm 0.4)^{\mathrm{a}}$} & - & $73.0^{a}$ \\
\hline & [1] & \multicolumn{2}{|l|}{$45.3( \pm 2.7)^{\mathrm{b}}$} & $0.5(0.1)^{b}$ & $22.9^{b}$ \\
\hline & [2] & \multicolumn{2}{|l|}{$37.1( \pm 3.5)^{b}$} & $1.4(0.2)^{b}$ & $19.3^{b}$ \\
\hline & [3] & \multicolumn{2}{|l|}{$33.7( \pm 3.3)^{b}$} & $0.7( \pm 0.1)^{b}$ & $17.2^{b}$ \\
\hline & & Epoxide & Enol & Enone & \\
\hline & [1] & $2.2( \pm 06)$ & $18.2( \pm 1.2)$ & $22.4( \pm 1.9)$ & 42.9 \\
\hline & [2] & $3.5( \pm 03)$ & $21.8( \pm 1.6)$ & $27.7( \pm 12)$ & 53.0 \\
\hline & [3] & $1.8( \pm 01)$ & $17.2( \pm 1.0)$ & $31.6( \pm 34)$ & 50.6 \\
\hline & & Sulfoxide & & Sulfone & \\
\hline & [1] & $20.3( \pm 1.7)$ & & $0.3( \pm 0.0)$ & 20.6 \\
\hline & [2] & $40.1( \pm 1.7)$ & & $0.4( \pm 0.0)$ & 40.5 \\
\hline & [3] & $58.5( \pm 4.3)$ & & $0.7( \pm 0.0)$ & 59.2 \\
\hline & & Alcohol & & Ketone & \\
\hline & [1] & - & & $45.2( \pm 0.5)$ & 45.2 \\
\hline & [2] & - & & $41.6( \pm 0.5)$ & 41.6 \\
\hline & [3] & - & & $44.4( \pm 1.2)$ & 44.4 \\
\hline & & Alcohol & & Ketone & \\
\hline & [1] & $18.9( \pm 1.0)$ & & $39.9( \pm 0.4)$ & 58.7 \\
\hline & [2] & $17.2( \pm 0.4)$ & & $36.9( \pm 0.8)$ & 54.1 \\
\hline & [3] & $12.4( \pm 0.1)$ & & $45.8( \pm 1.2)$ & 58.2 \\
\hline
\end{tabular}



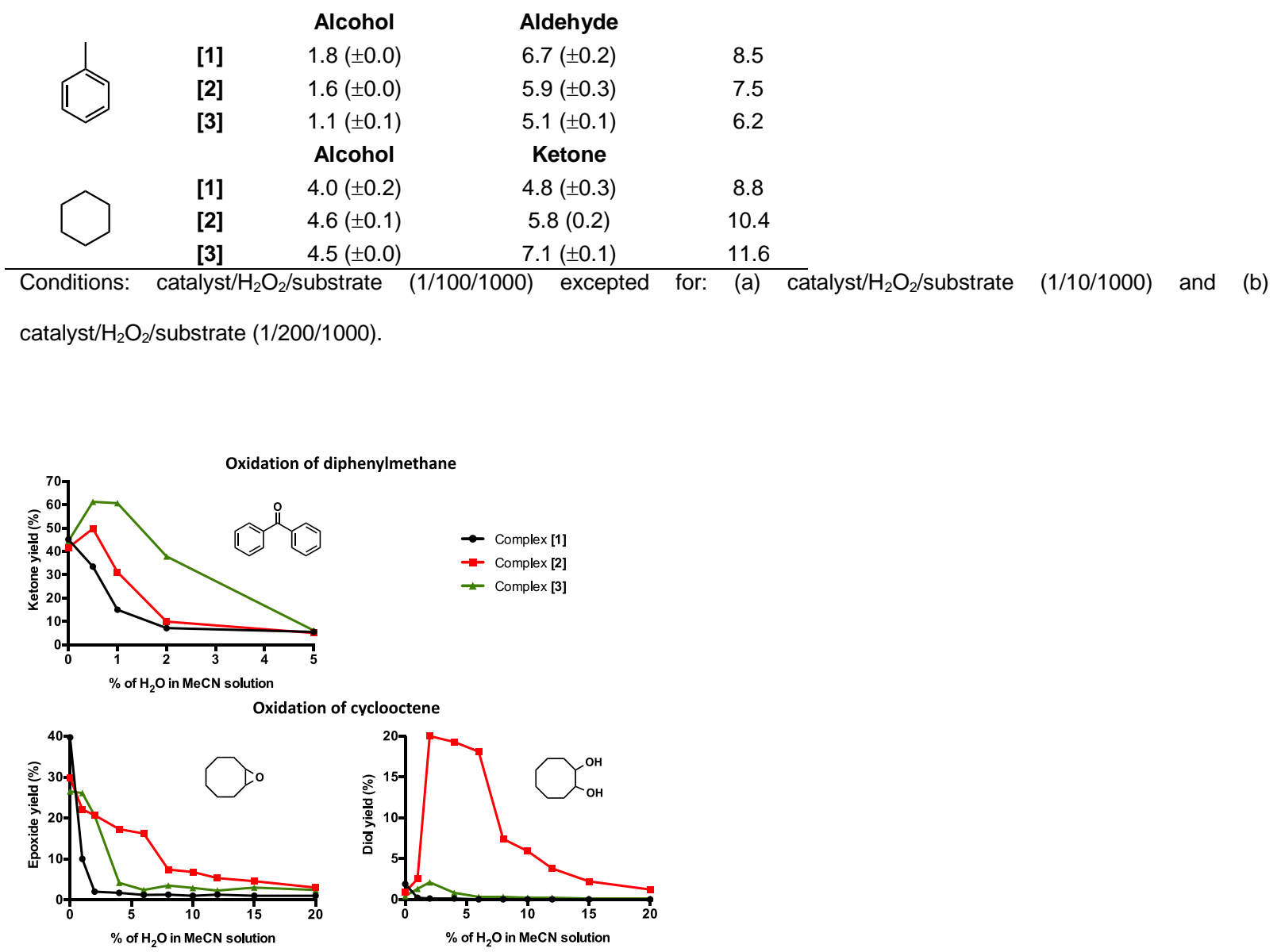

Figure 4. Oxidation reactions catalyzed by complexes [1] (black), [2] (red) and [3] (green) using $\mathrm{H}_{2} \mathrm{O}_{2}$ in $\mathrm{MeCN}$ solution with an increasing amount of $\mathrm{H}_{2} \mathrm{O}$.

In conclusion, we have synthesized and characterized two new symmetrical and unsymmetrical diiron complexes that proved to be efficient for alkene and alkane oxidations in acetonitrile solution. The addition of increasing amounts of water to the solution showed that the introduction of electron donating groups to the pyridyl ligand help maintaining and even improving catalysis in the presence of low proportion of water. Furthermore, the presence of water clearly modified both the catalytic activity and the selectivity of the unsymmetrical complex [2], which was not the case for symmetrical complexes [1] and [3].

\section{Conflicts of interest}

There are no conflicts to declare. 


\section{Notes and references}

1 A. J. Jasniewski and L. Que, Chem. Rev., 2018, 118, 2554-2592.

2 A. Trehoux, J.-P. Mahy and F. Avenier, Coor. Chem. Rev., 2016, 322, 142158.

3 C. E. Tinberg and S. J. Lippard, Acc. Chem. Res., 2011, 44, 280-288.

4 B. J. Wallar and J. D. Lipscomb, Chem. Rev., 1996, 96, 2625-2658.

5 I. Siewert and C. Limberg, Chem. Eur. J., 2009, 15, 10316-10328.

6 S. Menage, B. A. Brennan, C. Juarez-Garcia, E. Munck and L. Que, J. Am. Chem. Soc., 1990, 112, 6423-6425.

7 B. A. Brennan, Qiuhao. Chen, Carlos. Juarez-Garcia, A. E. True, C. J. O'Connor and Lawrence. Que, Inorg. Chem., 1991, 30, 1937-1943.

8 Y. Dong, S. Menage, B. A. Brennan, T. E. Elgren, H. G. Jang, L. L. Pearce and L. Que, J. Am. Chem. Soc., 1993, 115, 1851-1859.

9 A. L. Feig, M. Becker, S. Schindler, R. van Eldik and S. J. Lippard, Inorg. Chem., 1996, 35, 2590-2601.

10 L. Westerheide, F. K. Müller, R. Than, B. Krebs, J. Dietrich and S. Schindler, Inorg. Chem., 2001, 40, 1951-1961.

11 M. Costas, C. W. Cady, S. V. Kryatov, M. Ray, M. J. Ryan, E. V. RybakAkimova and L. Que, Inorg. Chem., 2003, 42, 7519-7530.

12 Y. Hayashi, T. Kayatani, H. Sugimoto, M. Suzuki, K. Inomata, A. Uehara, Y. Mizutani, T. Kitagawa and Y. Maeda, J. Am. Chem. Soc., 1995, 117, 11220-11229.

13 J. R. Frisch, V. V. Vu, M. Martinho, E. Münck and L. Que, Inorg. Chem., 2009, 48, 8325-8336.

14 L. H. Do, H. Wang, C. E. Tinberg, E. Dowty, Y. Yoda, S. P. Cramer and S. J. Lippard, Chem. Commun., 2011, 47, 10945-10947. 
15 Y. Dong, S. Yan, V. G. Young and L. Que, Angew. Chem. Int. Ed. Engl., 1996, $35,618-620$.

16 K. Kim and S. J. Lippard, J. Am. Chem. Soc., 1996, 118, 4914-4915.

17 T. Ookubo, H. Sugimoto, T. Nagayama, H. Masuda, T. Sato, K. Tanaka, Y. Maeda, H. Ōkawa, Y. Hayashi, A. Uehara and M. Suzuki, J. Am. Chem. Soc., 1996, $118,701-702$.

18 S. Friedle, E. Reisner and S. J. Lippard, Chem. Soc. Rev., 2010, 39, 27682779.

19 M. Zhao, B. Helms, E. Slonkina, S. Friedle, D. Lee, J. DuBois, B. Hedman, K. O. Hodgson, J. M. J. Fréchet and S. J. Lippard, J. Am. Chem. Soc., 2008, 130, 4352-4363.

20 X. Sun, S. V. Kryatov and E. V. Rybak-Akimova, Dalton Trans., 2013, 42, $4427-4435$.

21 L. Benhamou, A. Thibon, L. Brelot, M. Lachkar and D. Mandon, Dalton Trans., 2012, 41, 14369-14380.

22 O. Cussó, I. Garcia-Bosch, X. Ribas, J. Lloret-Fillol and M. Costas, J. Am. Chem. Soc., 2013, 135, 14871-14878.

23 O. V. Makhlynets, W. N. Oloo, Y. S. Moroz, I. G. Belaya, T. D. Palluccio, A. S. Filatov, P. Muller, M. A. Cranswick, L. Que and E. V. Rybak-Akimova, Chem. Commun., 2014, 50, 645-648.

24 G. Xue, D. Wang, R. De Hont, A. T. Fiedler, X. Shan, E. Münck and L. Que, Proc. Natl. Acad. Sci. USA, 2007, 104, 20713-20718.

25 G. Xue, R. De Hont, E. Münck and L. Que, Nat. Chem., 2010, 2, 400-405.

26 D. Wang, E. Farquhar, A. Stubna, E. Münck and L. Que, Nat. Chem., 2009, 1, 145-150. 
27 S. Ménage, J.-B. Galey, J. Dumats, G. Hussler, M. Seité, I. G. Luneau, G. Chottard and M. Fontecave, J. Am. Chem. Soc., 1998, 120, 13370-13382.

28 F. Avenier, L. Dubois, P. Dubourdeaux and J.-M. Latour, Chem. Commun., 2005, 480-482.

29 M. Yamashita, H. Furutachi, T. Tosha, S. Fujinami, W. Saito, Y. Maeda, K. Takahashi, K. Tanaka, T. Kitagawa and M. Suzuki, J. Am. Chem. Soc., 2006, 129, 23.

30 M. Kodera, M. Itoh, K. Kano, T. Funabiki and M. Reglier, Angew. Chem. Int. Ed., 2005, 44, 7104-7106.

31 M. Kodera, Y. Kawahara, Y. Hitomi, T. Nomura, T. Ogura and Y. Kobayashi, J. Am. Chem. Soc., 2012, 134, 13236-13239.

32 M. Kodera, S. Ishiga, T. Tsuji, K. Sakurai, Y. Hitomi, Y. Shiota, P. K. Sajith, K. Yoshizawa, K. Mieda and T. Ogura, Chem. Eur. J., 2016, 22, 5924-5936.

33 A. Trehoux, Y. Roux, R. Guillot, J.-P. Mahy and F. Avenier, J. Mol. Catal. A: Chem., 2015, 396, 40-46. 